\title{
A quantitative model of human neurodegenerative diseases involving protein aggregation
}

\author{
Kasper P. Kepp
}

Technical University of Denmark, DTU Chemistry, Building 206, 2800 Kgs. Lyngby, DK Denmark. *Phone: +045 452524 09. E-mail: kpj@kemi.dtu.dk

\begin{abstract}
Human neurodegenerative diseases such as Alzheimer's disease, Parkinson's disease, and Amyotrophic lateral sclerosis involve protein aggregation and share many other similarities. It is widely assumed that the protein aggregates exhibit a specific molecular mode of toxic action. This paper presents a simple mathematical model arguing that clinical cognitive status relates to the energy available after subtracting cell maintenance due to general turnover of the misfolded proteins, rather than a specific toxic molecular action per se. Proteomic cost minimization can explain why highly expressed proteins changed less during evolution, leaving more energy for reproducing microorganisms on longer evolutionary timescales. In higher organisms, the excess energy instead defines cognitive capability, and the same equations remarkably apply. Proteomic cost minimization can explain why late-onset neurodegenerative diseases involve protein aggregation. The model rationalizes clinical ages of symptom onset for patients carrying pathogenic protein mutations: Unstable or aggregation-prone mutations confer a direct energy cost of turnover, but other risk modifiers also change the available cellular energy as ultimately defining clinical outcome. Proteomic cost minimization is consistent with current views on biomarker histories, explains conflicting data on overexpression models, and is supported by specific experiments showing that proteasome activity is required to confer toxicity to pathogenic mutants. The mechanism and model lend promise to a quantitative personalized medicine of neurodegenerative disease.
\end{abstract}

Keywords: Protein misfolding, proteasome, proteostasis, energy, neurodegeneration 


\section{Introduction}

Evolution is the fundamental process that has shaped proteomes by randomly mutating DNA and, by random drift or active selection, fixating some mutations in the populations[1,2]. The most prominent relationship of proteomics is that proteins that are highly expressed (i.e. featuring high copy numbers in cells) are more evolutionary conserved in prokaryotes[3] and eukaryotes[4], including mammals[5,6]. This so-called expression-rate (ER) anti-correlation shows that the abundance of proteins in a cell is somehow particularly important during the course of evolution[4,7]. Proteins also tend to use synthetically cheaper (in terms of ATP) amino acids in all kingdoms of life[8,9].

Apparently unrelated to this, millions of people worldwide suffer from age-induced neurodegenerative diseases associated with large deposits of aggregated proteins[10,11]. In Alzheimer's disease (AD), the so-called senile plaques consist mainly of regular $\beta$-sheet fibrils of the infamous $\beta$-amyloid peptide (A $\beta$ ); in Parkinson's disease (PD), the Lewis bodies are made up of the protein $\alpha$-synuclein; in amyotrophic lateral sclerosis (ALS) the deposits consist of superoxide dismutase 1 (SOD1)[12]. Consensus is establishing that these deposits are typically not pathogenic (although toxic) but that soluble protein oligomers inside the cells may attain a pathogenic molecular mode of action. The many histopathological and clinical similarities of these diseases (protein deposits, age-triggering, oxidative stress associated, neurodegenerative) imply a common pathogenesis of protein misfolding[10,13].

Whereas aggregation is cytotoxic and potentially related to disease[14-17], the cellular pathogenic mechanism is unknown and not yet understood[10,14,18-23]. Efforts to identify and target the supposed malicious protein aggregates and oligomers, while possible with inhibitors or antibodies, have so far met with clinical failure[24-29]. This begs the question whether we miss a key determinant of disease course, and it is widely debated whether the protein aggregates in any particular shape and size are the root cause of disease or merely a side effect or contributing feature[10,28-30].

The hallmark protein deposits of the diseases suggest that protein homeostasis (also called proteostasis) is overwhelmed by an excess of misfolded proteins[31]. It is widely assumed that the misfolded proteins are pathogenic themselves by some specific molecular mode of action[32,33]. Although many suggestions have arisen[34], a single, specific molecular mechanism of action has not been identified, and accordingly there are no causative treatments available. Focus now centers 
on the intracellular oligomers that precede the fibrils; these oligomers are soluble and more toxic to cultured cells than fibrils[34-36]. The oligomers are targeted without actually knowing their bioactive structure, exact location, and the pathogenic process in which they are involved. They interact with many other molecules and cell parts, preventing the identification of a single pathogenic mode of in vivo action[27,37]. Efforts to reduce the production of the misfolding proteins by inhibitors or reduce oligomer activity by antibodies, which work in simpler tests, have failed to benefit the human patient[26,28,29,38].

The introduction of a new misfolded protein can overwhelm the existing proteostasis[39]; and some protein misfolding diseases may be transmitted (e.g. prion diseases and controversially suggested, $\mathrm{AD}$ [40,41]). Considering the variety of chemical targets within a cell, it is hard to perceive a single molecular mode of action caused by seeding- the mechanism must be generic and involve many kinds of proteins. Such observations beg a formal framework of understanding. The simplest possibility is that oligomers act by a generic mechanism such as membrane permeability disruption by pore formation[42-44], but this still requires a connection to the clinical outcome.

It is widely assumed that the protein aggregation itself is pathogenic, because of the toxicity seen in cultured cells and because genetic mutations causing severe early-onset disease occur in the aggregated proteins (e.g. SOD1 in ALS, $\alpha$-synuclein in PD, APP and PSEN1 in AD). The mutations, due to their penetration and common dominant inheritance, are often though to gain a toxic function[45-47], although a loss of natural function is also debated for these proteins[30,48$50]$.

\section{The model of proteomic cost minimization}

The model of proteomic cost minimization as a basis for protein evolution[51] is briefly reviewed below. The E-R anti-correlation has been explained[52,53] as a selection against inefficient translation leading to misfolded proteins. Highly expressed proteins would then be under a stronger selection pressure since the copy number of misfolded proteins $U_{\mathrm{i}}$ scales with the total abundance of the protein $A_{\mathrm{i}}$. An empirical equation for the fitness cost $\Phi_{\mathrm{i}}$ has thus been suggested[52]:

$$
\Phi_{i} \propto \exp \left(-c U_{i}\right)
$$

In this equation, $c$ is an unknown dimensionless fitness cost constant of one misfolded protein. 
To understand this observation at the molecular level, we first introduce a simplified protein turnover scheme, which provides the timeframe of the problem. The proteostasis of any protein $i$ can be written in a simplified way as[51]:

$$
m R N A_{i} \stackrel{k_{s_{i}}}{\rightarrow} F_{i} \underset{k_{2_{i}}}{\stackrel{k_{1_{i}}}{\rightleftharpoons}} U_{i} \stackrel{k_{d_{i}}}{\rightarrow} D_{i}
$$

In this scheme, $F_{i}$ represents the folded protein copies within the cell, $U_{i}$ represents misfolded protein copies, and $D_{i}$ are degraded chemical products, with the rate constants of each step annotated. $k_{d_{i}}$ is the rate constant (in units of protein molecules per second) for degradation of the misfolded protein copies. Since many values of degradation rate constants of proteins are known, we also know that the values of $k_{d_{i}}$ vary greatly with the protein $i$.

We now introduce an estimate of $U_{\mathrm{i}}$ assuming that the misfolded protein arises from a simple two-state folding process. If so, we have:

$$
U_{i}=A_{i}\left(\frac{1}{1+\exp \left(\frac{-\Delta G_{i}}{R T}\right)}\right)
$$

$A_{\mathrm{i}}$ represents the total copy number of the protein within the cell, $\Delta G_{i}$ is the folding stability (measured as a negative number in $\mathrm{kJ} / \mathrm{mol}$ ) of this protein and $R T$ is the thermal energy of the cell at $37^{\circ} \mathrm{C}$. In the limit of infinite protein stability $\left(\Delta G_{i} \rightarrow-\infty\right), U_{\mathrm{i}} \rightarrow 0$. The cellular maintenance energy (in $\mathrm{J} \mathrm{s}^{-1}$ ) allocated to one protein $i$ per time unit can then be derived as[51]:

$$
d E_{m, i} / d t=A_{i}\left(\frac{1}{1+\exp \left(\frac{-\Delta G_{i}}{R T}\right)}\right) k_{d_{i}} N_{a a_{i}}\left(C_{s_{i}}+C_{d_{i}}\right)
$$

$N_{a a_{i}}$ is the number of amino acids in protein $i$, whereas $C_{s_{i}}$ and $C_{d_{i}}$ represent the average synthetic and degradation cost (in units of $\mathbf{J}$ ) per amino acid in protein $i[51]$.

Equation (4) is for one protein. Let us now write the total protein turnover cost per time unit as the sum of the turnover costs of all proteins within the cell:

$$
d E_{m} / d t=\alpha \sum_{i} d E_{m, i} / d t=\alpha \sum_{i} A_{i}\left(\frac{1}{1+\exp \left(\frac{-\Delta G_{i}}{R T}\right)}\right) k_{d_{i}} N_{a a_{i}}\left(C_{s_{i}}+C_{d_{i}}\right)
$$

Energy costs are seen to scale with $A_{\mathrm{i}}$. Copy numbers $A_{\mathrm{i}}$ vary greatly with the type of protein $i$ (typically from zero to $10^{6}$ ) and thus some proteins are substantially more systemically important 
to the energy state as explained by Equation (5). We have included the possibility that the activity of protein turnover affects the total cost by a constant representing an effective concentration of proteases as determining the activity of the proteasome, called $\alpha$ in Equation (5). This constant multiplies with $k_{d_{i}}$ and thus scales the energy cost per time unit.

The energy cost per time unit of the proteome, Equation (5), explains the E-R correlation: One first assumes that the fitness is given by the energy available for reproduction $d E_{r} / d t$ after subtracting the energy cost of Equation (5) (ignoring non-proteome energy costs) from the total produced energy of the cell $d E_{t} / d t$ :

$$
\Phi_{i}=d E_{r} / d t=d E_{t} / d t-d E_{m} / d t
$$

In the simple case where the total energy production is constant, minimization of $d E_{m} / d t$ maximizes fitness. From Equation (4), fitness (and hence the selection coefficient) scales with the abundance of the protein. Accordingly, abundant proteins are under stronger selection pressure for cost minimization, making them less likely to accept random (on average destabilizing) mutations and thus conserving them more over evolutionary time. Because the exponential of Equation (1) can be expanded as $1-\mathrm{c} U_{\mathrm{i}}$ due to the small values of $\mathrm{c} U_{\mathrm{i}}$, this theory recovers and explains the phenomenological fitness cost constant $c$ of Equation (1) in terms of fundamental protein turnover parameters[51].

Among costly processes, protein synthesis accounts for $\sim 30 \%$ of resting energy expenditure in $\operatorname{man}[54,55]$ and typically $\sim 75 \%$ in growing microorganisms[56]. Typical costs are $\sim 10 \mathrm{~kJ}$ per gram protein, at about 3-5 grams of protein produced per kg mass per day[55]. A typical adult human thus synthesizes 200-300 grams of protein per day, spending 2000-3000 kJ on this process alone per day out of a total basic metabolic rate of perhaps $6000 \mathrm{~kJ} / \mathrm{day}^{3}$. Protein degradation may cost another $20 \%$ of the mammalian total energy expenditure[57], making protein turnover the most energy-consuming process of the body.

\section{Energy model of neurodegenerative disease}

In the following, the fitness function of Equation (6) is argued to also describe a cognitive status function of the brain. Equation (6) defines the energy available after subtracting maintenance costs from the produced energy. Now instead of microorganisms spending their surplus energy on 
reproduction, higher organisms use a large part ( 20\%) of their surplus energy for cognition and brain function [58-61]. In higher organisms, we can then consider $d E_{r} / d t$ as energy available for cognitive execution, dominated by the $\sim 50 \%$ energy spent on the ion pumps $[59,62]$. To distinguish it, we call it $d E_{x} / d t$ :

$$
\frac{d E_{x}}{d t}=\frac{d E_{t}}{d t}-\alpha \sum_{i} A_{i}\left(\frac{1}{1+\exp \left(\frac{-\Delta G_{i}}{R T}\right)}\right) k_{d_{i}} N_{a a_{i}}\left(C_{S_{i}}+C_{d_{i}}\right)
$$

In this simplest model, the energy available for cognition has been reduced to a function only of proteome turnover costs, summed over all proteins $i$. Of course, other costs can easily be included in such a model, but the purpose at this point is to show how protein misfolding relates to the clinical outcome, which we take as $d E_{x} / d t$. Thus, any impairment of $d E_{x} / d t$ caused either by a reduction in $d E_{t} / d t$ or an increase in maintenance energy $d E_{m} / d t$ will reduce cognitive capacity.

From Equation (7), any protein that is associated with an increased abundance $A_{i}$, turnover constant $k_{d_{i}}$, loss of stability to increase the pool of unfolded proteins, Equation (5), or an increase in the specific synthesis and degradation costs of the amino acids $C_{s_{i}}+C_{d_{i}}$ will increase maintenance. Please note that the bias towards synthetically cheap amino acids seen in real protein sequences is largely reflected in the parameter $C_{S_{i}}$. Many other risk factors can be expected to influence either $d E_{m} / d t$ or $d E_{t} / d t$. A summary of this mechanism of neurodegeneration is given in Figure 1, with energy status being the central determinant of cell fate and cognitive capacity.

Energy production typically decreases with age and the energy needed for maintenance increases with age, as seen from the increase in maintenance and stress-related proteins in the aging human brain[63], particular changes in AD[64], and from the glucose biomarkers[65,66]. For simplicity, we first assume that the deceleration in energy production and the acceleration in maintenance costs are constant over time. If so we have:

$$
\frac{d E_{t}}{d t}=\left(\frac{d E_{t}}{d t}\right)_{0}-C_{t} t
$$




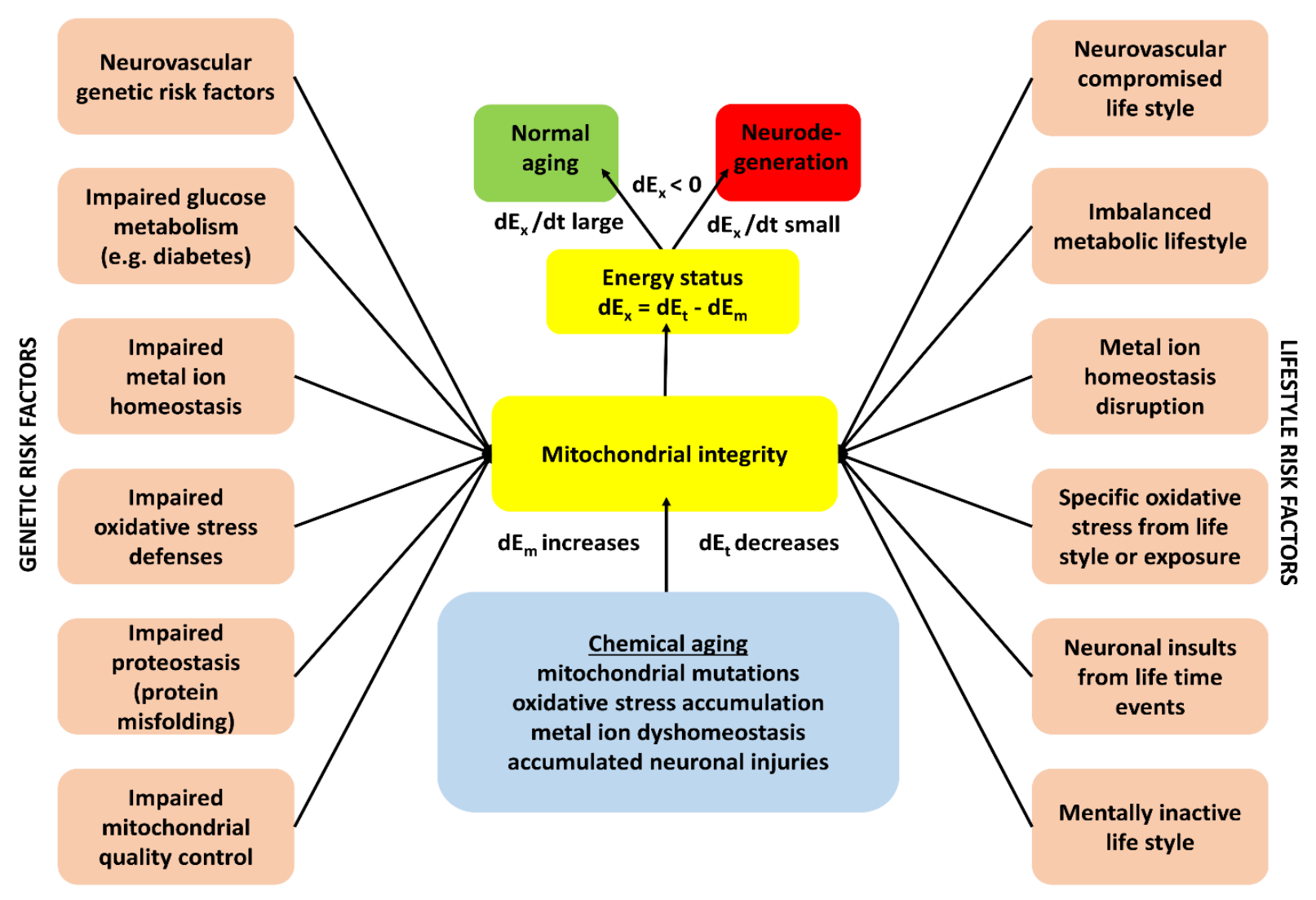

Figure 1. Summary of the exhaustion mechanism of neurodegeneration. Genetic and life style risk factors affect the energy balance of the brain by elevating maintenance costs $\left(\mathrm{dE}_{\mathrm{m}}\right)$ or lowering total energy production $\left(\mathrm{dE}_{\mathrm{t}}\right)$. If the process occurs gradually, normal aging is observed. If the process is accelerated, the cost of maintenance will increase faster than the ability to compensate energy loss, leading to neurodegeneration when $\mathrm{dE}_{\mathrm{m}} \sim \mathrm{dE}_{\mathrm{t}}$.

$$
\frac{d E_{m}}{d t}=\left(\frac{d E_{m}}{d t}\right)_{0}+C_{m} t
$$

Here, $C_{t}$ and $C_{m}$ are the constants of change in the energy production and maintenance costs per time unit, respectively. Accordingly:

$$
\frac{d E_{x}}{d t}=\left(\frac{d E_{t}}{d t}\right)_{0}-\left(\frac{d E_{m}}{d t}\right)_{0}-\left(C_{t}+C_{m}\right) t
$$


Thus, the energy available for cognition is a function of four variables: The genetically encoded starting respiration rates of energy production and maintenance costs, and the specific constant changes in these two processes:

$$
C_{t}=\frac{d^{2} E_{t}}{d t^{2}} \quad \text { and } \quad C_{m}=\frac{d^{2} E_{m}}{d t^{2}}
$$

The model is shown in Figure 2A-C, using a healthy normality index of 100, with a 50\% cost of total energy devoted to maintenance at $\mathrm{t}=0$. Because of the constant changes in energy production and maintenance, linear changes are seen in $\mathrm{d} E_{\mathrm{t}} / \mathrm{dt}, \mathrm{d} E_{\mathrm{m}} / \mathrm{dt}$, and accordingly, $\mathrm{d} E_{\mathrm{x}} / \mathrm{dt}$. For simplicity, the clinical age of onset is assumed to be the point of intersection where $\mathrm{d} E_{\mathrm{X}} / \mathrm{dt}=0$ (dashed lines). The simplest loss of function phenotype would manifest as a larger $C_{\mathrm{t}}$, the reduction rate of the energy production, whereas the simplest gain of function mechanism would accelerate maintenance costs, $C_{\mathrm{m}}$. Mixtures of these situations are possible. These two situations correspond to Figure 2B and 2C, where values of $C_{\mathrm{m}}=0.5$ and $C_{\mathrm{t}}=0.5$ have been used respectively, whereas in the "normal" case of Figure $2 \mathrm{~A}, C_{\mathrm{m}}=0.25$ and $C_{\mathrm{t}}=0.25$. The approximate relationship $\mathrm{dE} / \mathrm{dt}$ $\sim \mathrm{dE}_{\mathrm{x}} / \mathrm{dt} \sim 1 / 2 \mathrm{dE}_{\mathrm{t}} / \mathrm{dt}$ holds for a normal brain[59,62].

The age of clinical symptom onset is defined as the time where the surplus energy available for cognition becomes zero, $d E_{x} / d t=0$ :

$$
t_{\text {onset }}=t \mid \frac{d E_{t}}{d t}=\frac{d E_{m}}{d t}
$$

This situation can importantly be modeled as simple constant acceleration as seen in Figure 2A2C. In this simple case, the age of clinical onset simply becomes:

$$
t_{\text {onset }}=\frac{\left(\frac{d E_{t}}{d t}\right)_{0}-\left(\frac{d E_{m}}{d t}\right)_{0}}{\left(C_{m}+C_{t}\right)}
$$

The parameters are the average values for the full cells of the affected cell types. Clinical age of onset depends on the basic energy production and maintenance costs, modified by the accelerated costs and decelerated energy production during aging. All four terms can vary between individual patients as a function of risk modifiers.

Let us for simplicity consider the situation where the patient has normal energy production throughout life, but has increasingly elevated maintenance costs. This can be due to either increased basic maintenance costs or an elevated rate of increase in maintenance costs, the latter shown in Figure 2B, described as: 

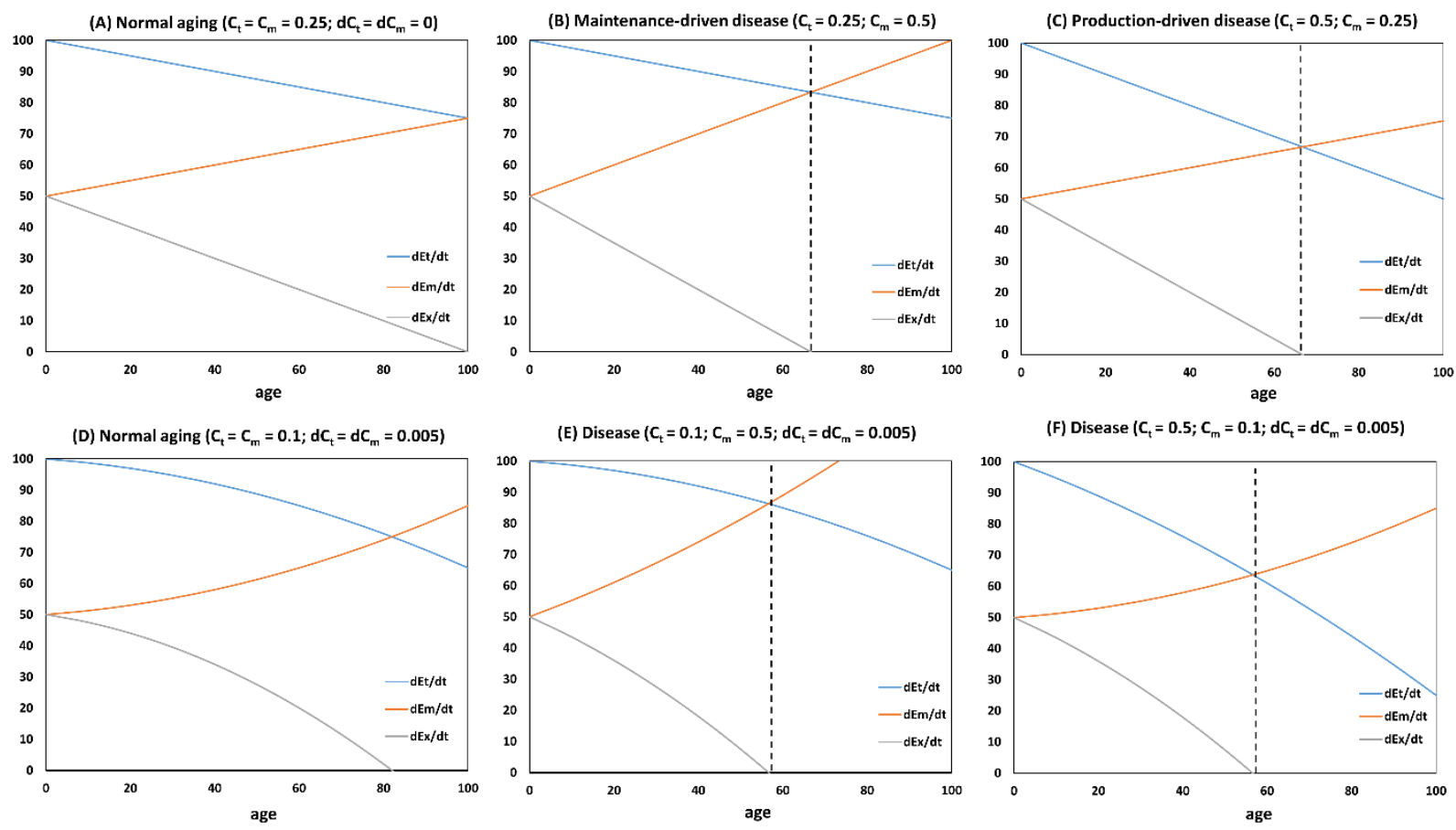

Figure 2. Six scenarios of proteomic cost driven neurodegenerative disease. (A) Normal aging with constant changes in energy production and maintenance $\left(C_{\mathrm{t}}=C_{\mathrm{m}}=0.25 ; \mathrm{d} C_{\mathrm{t}}=\mathrm{d} C_{\mathrm{m}}=0\right) ;(\mathbf{B})$ disease driven by increased maintenance costs $\left(C_{\mathrm{t}}=0.25 ; C_{\mathrm{m}}=0.5 ; \mathrm{d} C_{\mathrm{t}}=\mathrm{d} C_{\mathrm{m}}=0\right) ;(\mathbf{C})$ disease driven by reduced energy production $\left(C_{\mathrm{t}}=0.5 ; C_{\mathrm{m}}=0.25 ; \mathrm{d} C_{\mathrm{t}}=\mathrm{d} C_{\mathrm{m}}=0\right) ;(\mathbf{D})$ model of accelerated aging ("viscous cycle") where the rate of change varies $\left(\mathrm{d} C_{\mathrm{t}}=\mathrm{d} C_{\mathrm{m}}=0.005\right)$ for a normal person $\left(C_{\mathrm{t}}=C_{\mathrm{m}}=0.1\right) ;(\mathbf{E})$ as in $(\mathbf{D})$ but with $C_{\mathrm{m}}=0.5 ;(\mathbf{F})$ as in $(\mathbf{D})$ but for a patient with $C_{\mathrm{t}}=0.5$.

$$
\frac{d E_{\chi}}{d t}=\left(\frac{d E_{t}}{d t}\right)_{0}-\left(\frac{d E_{m}}{d t}\right)_{0}-C_{t} t-\frac{d}{d t} \alpha \sum_{i} A_{i}\left(\frac{1}{1+\exp \left(\frac{-\Delta G_{i}}{R T}\right)}\right) k_{d_{i}} N_{a a_{i}}\left(C_{S_{i}}+C_{d_{i}}\right) t
$$

The case in Figure 2B represents increased $C_{\mathrm{m}}$. Several of the parameters in Equation (14) can easily be time-dependent. For example, the amount of misfolded protein may increase due to destabilization caused by oxidative stress other forms of chemical aging. Proteins that are easily and quickly degraded (large $k_{d_{i}}$ ) pose a particular challenge to the maintenance costs, but in proportion to their abundance. Thus, the combination of abundant and quickly degraded proteins is the most severe problem in Equation (14). 
The model can estimate the clinical age of onset of carriers of familial disease mutations as a function of the severity of a protein mutant. For example, SOD1 mutants causing severe FALS generally exhibit a reduced stability or net charge, which both work to increase the misfolding and turnover of this important and abundant (i.e. large $A_{\mathrm{i}}$ ) protein $[45,67,68]$. The increased cost of maintaining the mutant SOD1 copies folded causes motor neurons to have less energy available for execution over longer time, when total energy budgets become stressed (Figure 2). Typical SOD1 mutants reduce $\Delta G_{i}$ by $5-10 \mathrm{~kJ} / \mathrm{mol}[69-71]$.

A typical decrease $\Delta G_{i}$ of $5 \mathrm{~kJ} / \mathrm{mol}$ will double the copy number of misfolded proteins in the cell (Equation 3) regardless of the abundance, and in any reasonable range of $\Delta G_{i}$ (-20 to -100 $\mathrm{kJ} / \mathrm{mol}$ ) so this effect is generic. Equation (13) measures the total $C_{\mathrm{m}}$ for the cell; a doubling of cost of one protein will raise total $C_{\mathrm{m}}$ by a very small amount. An abundant protein with 100,000 copies would still constitute less than a percentage of total protein in the cell. An increase in total $C_{\mathrm{m}}$ of $1 \%$ would not drive disease in a linear model (Figure 2A-2C). A simple linear model is also unlikely considering the inherent accelerations in energy depletion and oligomer buildup: Any deficiency of energy will leave more oligomers and accelerate maintenance cost over time. In such a process, oligomers and associated energy cost build up exponentially until saturation:

$$
\frac{d E_{m}}{d t}=\left(\frac{d E_{m}}{d t}\right)_{0} \exp (-C t)
$$

where $C$ is the depletion rate constant. Biomarker studies suggest that the disease progression increases nonlinearly and saturates at long times, giving a sigmoidal shape[72].

Let us therefore study a model where $C_{\mathrm{m}}$ and $C_{\mathrm{t}}$ increase with time, due to accelerating turnover costs per time. The mechanistic basis is that lack of energy can affect other features such as depolarization of neurons, excitotoxicity, calcium, zinc, and copper imbalances, and oxidative stress that may feed back and aggravate the continuous loss of $\mathrm{dE}_{\mathrm{x}} / \mathrm{dt}[43,73-76]$. Figure 2D-2F shows the model where the change in maintenance cost accelerates with aging to produce nonlinear, accelerated disease progressions. Even a small acceleration of the maintenance costs can move clinical symptom onset to much earlier age. Mutations that not only increase turnover costs but do so increasingly with chemical aging is described by this situation[77-80]. Whereas the linear scenario is unlikely to lead to disease via a single protein's impact on the total value of $C_{\mathrm{m}}$, the non-linear scenario in Figure 2D-2F is feasible even at small initial perturbations of the proteostatic machinery. 


\section{Modeling disease histories and biomarkers}

The energy model of neurodegeneration as formulated above implies that disease can be more or less severe, depending on the rate of depletion of energy resources. Also, the many risk modifiers will modulate the disease history of a patient in a way that may be modeled. Figure 3 illustrates a simple disease history for $\mathrm{AD}$, based on the much used framework by Jack et al.[72] Glucose uptake is impaired as the earliest measurable event, followed by A $\beta$ pathology[72]. A patient with a mutation that produces oligomers subject to intensive proteolysis will exhaust the energy status of the neurons faster than the typical patient; this would lead to an early-onset form of the disease, shifting the age of onset towards the left of Figure 3. Since this clinical age of onset is directly defined by Equation 12, using for illustration an indexed level of function loss of 0.15 as threshold where disease symptoms are evident. In this way, the modeled disease progressions in Figure 2 can be mapped directly to the clinical disease progression of Figure 3.

To understand this in more detail, the non-linear progression of biomarkers[72] follows directly from the exponential aging model represented by the accelerated proteomic energy cost, Figure 2E and 2F: At any age, the buildup of pathogenic protein oligomers will accelerate because the energy left for degrading them decreases exponentially (Figure 2E, 2F). Because these oligomers are in an equilibrium with aggregated deposits, the deposits will increase exponentially until saturation is reached when the amount of aggregated protein does not increase further because cell death cancels the new production of aggregates and partly because the export of aggregates becomes unfavorable as the extracellular aggregate concentration increases. Thus the model rationalizes the clinical observed history of biomarkers.

The common explanation given for the sigmoidal shape of biomarkers [72] is that the shape parallels the in vitro aggregation assays, typically monitored by the $\beta$-sheet binding thioflavin $\mathrm{T}$, such that an elongation phase is followed by nucleation, leading to an exponential increase is aggregation until saturation. However, in a real neuron, it is very unlikely that this in vitro mechanism takes place considering the intracellular concentrations of proteins that will probably only form large aggregates outside the cell, but be constantly degraded as oligomers inside the cell. The model in Figure 2 provides an alternative, systemic explanation for the sigmoidal shape not due to aggregation kinetics but to accelerating exhaustion of turnover capacity. These two explanations for the observed sigmoidal biomarker histories are fundamentally different and may be tested in the future. 


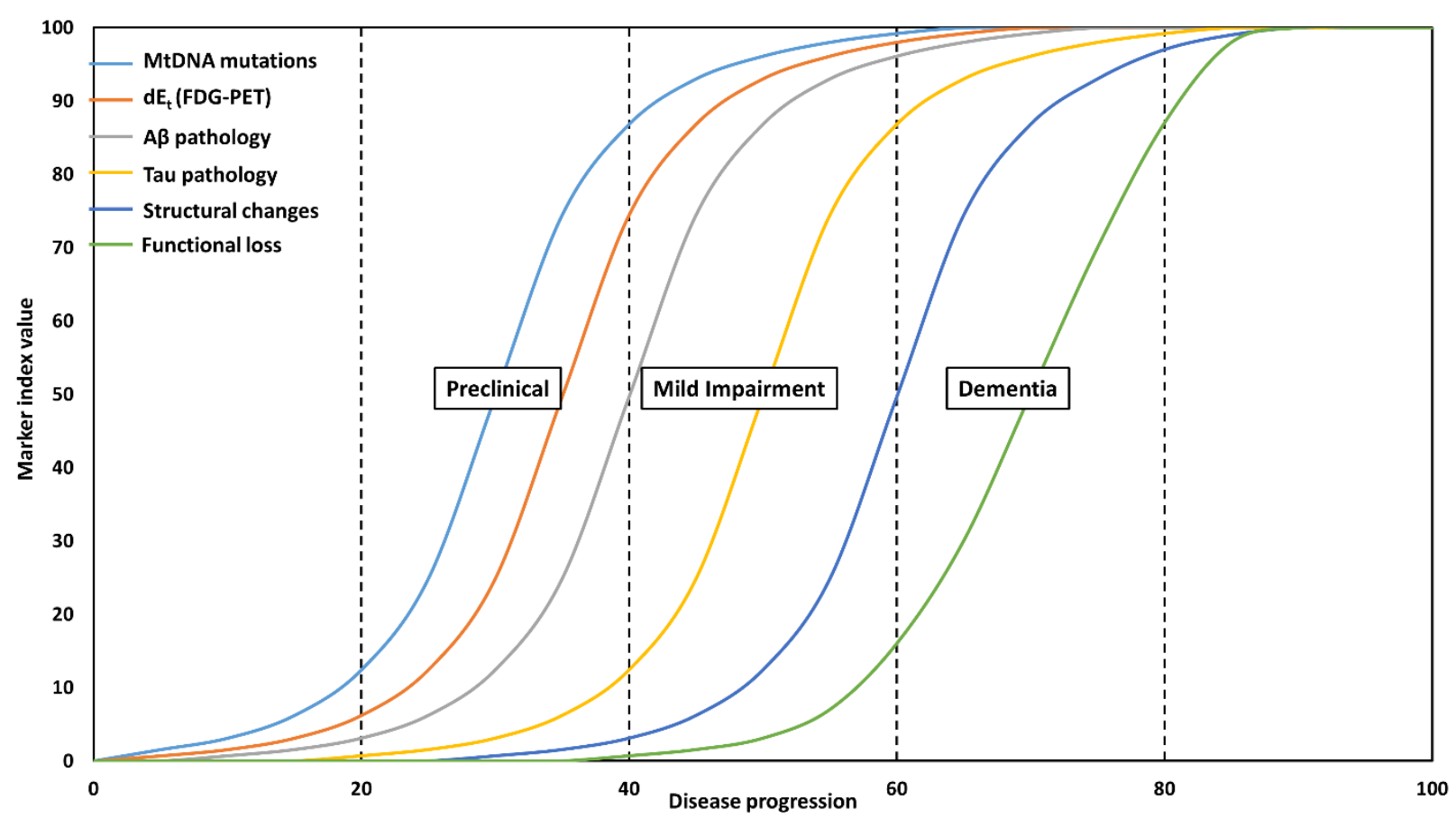

Figure 3. Approximate biomarker normalized index value (0-100) vs. hypothetical disease progression (from 0 to 100), based on a previous model[72]. Age of onset is arbitrarily chosen to be the point at which indexed functional loss is 0.15 (marked in stipulated lines as separating mild impairment from dementia) and can be estimated from Equation (13)-(15).

\section{Support for the model: Energy in the healthy brain and in disease}

The model immediately answers the haunting question why neurodegenerative diseases are protein misfolding diseases. A pool of misfolded proteins always exists in all cells but is kept very small, probably below one copy at any instance per cell due to fast turnover. The energy burden and thus disease only manifests in the most energy-requiring cells, including those of the central nervous system. The adult human brain typically uses $20 \%$ of the total resting energy, despite weighing only 1200-1500 grams, a few percent of total body mass[58,81-83]. Typically $50 \%$ of this brain energy is allocated to maintain the ion gradients central to neuronal signaling, whereas housekeeping takes up the second-largest contribution and includes protein synthesis and degradation costs[59,62]. The neuronal maintenance costs per time unit set the limit on the cognitive abilities via the temporal efficiency of information processing $[58,62]$. Despite the very high use of energy, very little energy is stored in the brain, and the neurons are thus extremely sensitive to the supply 
of energy[84]. Upon circulatory arrest, brain energy stores are used up within a few minutes[60]; thus $\mathrm{dE} / \mathrm{dt}$ rather than absolute energy stores is used in the model.

Age-induced impaired energy balance is associated with all major neurodegenerative diseases: Glucose abnormalities feature in both $\mathrm{PD}[65,85]$ and $\mathrm{AD}[86-88]$, and metabolic changes are associated with PD[89], AD[64,90], and ALS[91]. Diabetes and obesity are risk factors of neurodegenerative disease[87,90,92], as are genes related to cholesterol and lipoprotein homeostasis[93,94]. Energy deficiency has been suggested to be a major underlying cause of $\mathrm{AD}[30,86,95-97]$ and ALS[98-101], and deficiencies in mitochondrial respiration is a wellknown central feature of PD[89,102-104]. Reduced energy availability in AD is well-established and sets in before clinical symptoms[64,77,105].

AD has been viewed by some as a mitochondrial disease[78,106-109], and is strongly related to calcium dyshomeostasis[110-114]. Abnormal energy availability in the brain is a consistent feature of $\mathrm{AD}[93,115-117]$, and potential blood markers of AD relate to apoptosis and metabolism; clusterin, which is a risk factor and candidate biomarker, probably plays a central role in these pathways[118]. AD patients have reduced availability of glucose/insulin[86,97], and disruptions in metabolism and energy balance of the brain is an early feature of $\mathrm{AD}[90]$. The energy shortage is a key feature of $\mathrm{AD}[64,119]$, and $\mathrm{AD}$ is also characteristically a mitochondrial disease that reduces $\mathrm{dE}_{\mathrm{t}} / \mathrm{d}_{\mathrm{t}}$ relative to $\mathrm{dE} / \mathrm{dt}[107,120,121]$.

Combined $\mathrm{A} \beta$ and glucose exposure to microvascular endothelial cells cause enhanced cooperative chemical aging[122]. This suggests that $\mathrm{A} \beta$ plays a role in glucose metabolism, and $\mathrm{A} \beta$ can increase glucose tolerance[123]. One of the strongest lines of evidence for a direct connection between protein misfolding toxicity and accelerated aging related to disease comes from studies of $A \beta$ effects on insulin signalling[124].

PD is most likely caused by impaired ability to quality-control mitochondria of the affected cells, resulting in low energy production and associated energy shortage[89][65]. As is the case of $\mathrm{AD}$ and ALS, protein quality control is also impaired in $\mathrm{PD}[21]$, as is specifically the quality control of the energy-producing mitochondria, and parkin affects both mitochondrial quality control and glucose metabolism of the brain[85].

SOD1 aggregates in sporadic ALS, and mutations cause severe early-onset familial ALS (FALS)[101,125,126]. ALS patients experience increased resting energy expenditure that has not 
been rationalized[127],[91], but fits Equation (14) since SOD1 mutants almost invariably decrease stability and thus increase the pool of misfolding proteins requiring turnover. The observations that ALS-causing SOD1 mutants impair mitochondrial respiration[128,129] and cause metabolic abnormalities[130] support the direct relationship between protein turnover of aggregation-prone mutants and cellular energy claimed by Equation (14). Thus, the model suggests that ALS results from degeneration of motor neurons caused by depletion of the very large energy required for executing motor-neuron signaling[131]. There is now substantial support for this explanation[132134]. Additional elevated costs of turnover will contribute to Equation (14) as well via the proteasome parameter $\alpha$. As an example of the effect of the latter, functionally impaired variants of Ubiquilin-2 have been implicated as a risk factor in ALS[135].

Any increased turnover of a protein also involves a cost associated with RNA processing. Some mutations do not result in amino acid changes in the produced proteins but still cause disease. The GGGGCC hexanucleotide repeat expansion on chromosome 9, C9ORF72, accounts for many cases of ALS. Such repeat expansions will lead to abnormal RNA processing and transcriptional inefficiency[136], which we argue manifest as an increased ATP cost of the cell per time unit, i.e. an increase in $C_{\mathrm{m}}$ of Equation (14). Other recently identified genetic risk factors also affect RNA metabolism (TAR-DNA binding protein 43[137,138], FUS[139,140]) or protein processing (SQSTM1[141], VCP[142]). Also, TDP-43, a risk factor in ALS, has been suggested to modulate SOD1 levels[143].

If the model is correct, overexpression of any protein, if substantial enough, should potentially cause energy crisis and be toxic. This relates to the many models of disease where proteins are heavily overexpressed. Overexpression of non-pathogenic SOD1 wild-type proteins produce disease-like phenotypes, although these effects are smaller than for the pathogenic mutants[144]. These observations do not fit well with the standard models presuming an innocent wild type and a pathogenic mutant regardless of expression level, but are completely explained by Equation (14), where both the abundance $A_{\mathrm{i}}$ and the stability change contribute to the pool of misfolded proteins subject to turnover, and thus to the energy costs.

A simple, central experiment can further test whether the proteomic cost minimization model or the "molecular toxic action" mechanism is correct. It involves expressing pathogenic mutants with and without the protein being degraded. If the proteasome is inhibited during expression of the aggregation-prone mutants, disease would be aggravated if the misfolded 
proteins were toxic per se, because more toxic misfolded proteins would be available. However, if disease is mainly due to the energy burden of turnover, short-term proteasome inhibition concurrent with overexpression of pathogenic mutants should be less pathogenic than the same mutants expressed at the same levels without proteasome inhibition on a short time scale until the inhibition of protein turnover becomes systemically toxic.

It was recently shown that the pathogenic G85R mutant of SOD1 is not very toxic under normal conditions and during inhibition of the proteasome, but when the proteasome activity is recovered after inhibition, the soluble mutant oligomers become toxic[133]. The general assumption that a molecular mode of action makes misfolded proteins toxic is not supported by such experiments. Equation (14) explains it because the toxic mode of action is not by molecular activity of the misfolded protein copy, but by its associated turnover cost. Proteasome inhibition can lead to several-fold higher levels of SOD1 within the cell[145], which shows that the turnover an its disruption readily and to a sufficient extend changes the energy costs.

\section{Concluding remarks}

There is a pressing need for new fundamental understandings of neurodegenerative diseases and for models that can combine and rationalize the vast amount of data in the field. This paper provides such a model relating protein turnover directly to clinical outcome. The principle of proteome cost minimization holds that neurons are among the most energy-demanding cells in the body, that the cost of protein turnover reduces the energy left for ion pumping and thus cell signaling, and that the increased energy costs and reduced energy production produce a threshold where energy available for cognitive execution becomes critical, the age of symptom onset. Abundant, aggregation-prone proteins will increase maintenance cost proportionally and thus accelerate this age. Turning on and off the proteasome by inhibitors during pathogenic mutant expression in cultured cells should be a straightforward way to test the theory.

The equations suggests multiple strategies to address the diseases, notably by either increasing total energy availability, energy efficiency, or by reducing maintenance costs. Therapies that target those oligomers that are particularly subject to proteolysis in vivo are predicted to be most advantageous. The predictions are in contrast to those of the traditional view that protein aggregates have a specific toxic mode of action that should be targeted, and that any turnover of them, however costly, should be less important to disease course. Such clinical strategies have so 
far failed perhaps for the reasons stated in this work. Instead, the increasing evidence for the case of targeting either energy production, availability, or consumption[146] is largely consistent with the model described in the present work.

\section{Conflicts of interest}

The author declares that he has no financial or non-financial interests associated with this work.

\section{Acknowledgements}

The author acknowledges financial support from the Novo Nordisk Foundation, grant NNF17OC0028860, and the Danish Council for Independent Research | Natural Sciences (DFF), grant 7016-00079B.

\section{References}

[1] Presgraves DC (2010) The molecular evolutionary basis of species formation. Nat. Rev. Genet. 11, 175-180.

[2] Hurst LD (2009) Fundamental concepts in genetics: genetics and the understanding of selection. Nat. Rev. Genet. 10, 83-93.

[3] Sharp PM (1991) Determinants of DNA sequence divergence between Escherichia coli and Salmonella typhimurium: Codon usage, map position, and concerted evolution. $J$. Mol. Evol. 33, 23-33.

[4] Pál C, Papp B, Hurst LD (2001) Highly expressed genes in yeast evolve slowly. Genetics 158, 927-931.

[5] Jordan IK, Mariño-Ramírez L, Wolf YI, Koonin E V (2004) Conservation and coevolution in the scale-free human gene coexpression network. Mol. Biol. Evol. 21, 2058-2070.

[6] Zhang L, Li W-H (2004) Mammalian housekeeping genes evolve more slowly than tissue- 
specific genes. Mol. Biol. Evol. 21, 236-239.

[7] Drummond DA, Bloom JD, Adami C, Wilke CO, Arnold FH (2005) Why highly expressed proteins evolve slowly. Proc. Natl. Acad. Sci. U. S. A. 102, 14338-14343.

[8] Wagner A (2005) Energy constraints on the evolution of gene expression. Mol. Biol. Evol. 22, 1365-1374.

[9] Seligmann H (2003) Cost-minimization of amino acid usage. J. Mol. Evol. 56, 151-161.

[10] Bucciantini M, Giannoni E, Chiti F, Baroni F, Formigli L, Zurdo J, Taddei N, Ramponi G, Dobson CM, Stefani M (2002) Inherent toxicity of aggregates implies a common mechanism for protein misfolding diseases. Nature 416, 507.

[11] Soto C, Pritzkow S (2018) Protein misfolding, aggregation, and conformational strains in neurodegenerative diseases. Nat. Neurosci. 21, 1332-1340.

[12] Andersen PM (2006) Amyotrophic lateral sclerosis associated with mutations in the CuZn superoxide dismutase gene. Curr. Neurol. Neurosci. Rep. 6, 37-46.

[13] Gan L, Cookson MR, Petrucelli L, La Spada AR (2018) Converging pathways in neurodegeneration, from genetics to mechanisms. Nat. Neurosci. 21, 1300-1309.

[14] Bruijn LI (1998) Aggregation and Motor Neuron Toxicity of an ALS-Linked SOD1 Mutant Independent from Wild-Type SOD1. Science 281, 1851-1854.

[15] Pauwels K, Williams TL, Morris KL, Jonckheere W, Vandersteen A, Kelly G, Schymkowitz J, Rousseau F, Pastore A, Serpell LC, Broersen K (2012) Structural basis for increased toxicity of pathological a $342: \mathrm{a} \beta 40$ ratios in Alzheimer disease. J. Biol. Chem. 287, 5650-5660.

[16] Brouillette J, Caillierez R, Zommer N, Alves-Pires C, Benilova I, Blum D, De Strooper B, Buee L (2012) Neurotoxicity and Memory Deficits Induced by Soluble Low-MolecularWeight Amyloid- $\beta$ 1-42 Oligomers Are Revealed In Vivo by Using a Novel Animal Model. J. Neurosci. 32, 7852-7861.

[17] Tiwari MK, Kepp KP (2015) Modeling the Aggregation Propensity and Toxicity of Amyloid- $\beta$ Variants. J. Alzheimer's Dis. 47, 215-229.

[18] Hardy JA, Higgins GA (1992) Alzheimer's disease: the amyloid cascade hypothesis. 
Science 256, 184-185.

[19] Hardy J, Selkoe DJ (2002) The amyloid hypothesis of Alzheimer's disease: progress and problems on the road to therapeutics. Science 297, 353-356.

[20] Dobson CM (2003) Protein folding and misfolding. Nature 426, 884-90.

[21] Cook C, Stetler C, Petrucelli L (2012) Disruption of protein quality control in Parkinson's disease. Cold Spring Harb. Perspect. Med. 2, a009423.

[22] Knowles TPJ, Vendruscolo M, Dobson CM (2014) The amyloid state and its association with protein misfolding diseases. Nat. Rev. Mol. cell Biol. 15, 384-396.

[23] Eisenberg D, Jucker M (2012) The amyloid state of proteins in human diseases. Cell 148, 1188-1203.

[24] Gregersen N, Bross P, Vang S, Christensen JH (2006) Protein misfolding and human disease. Annu. Rev. Genomics Hum. Genet. 7, 103-124.

[25] Chiti F, Dobson CM (2017) Protein Misfolding, Amyloid Formation, and Human Disease: A Summary of Progress Over the Last Decade. Annu. Rev. Biochem. 86, 27-68.

[26] De Strooper B, Chávez Gutiérrez L (2015) Learning by Failing: Ideas and Concepts to Tackle $\gamma$-Secretases in Alzheimer's Disease and Beyond. Annu. Rev. Pharmacol. Toxicol. 55, 419-437.

[27] Karran E, Hardy J (2014) A critique of the drug discovery and phase 3 clinical programs targeting the amyloid hypothesis for Alzheimer disease. Ann. Neurol. 185-205.

[28] Herrup K (2015) The case for rejecting the amyloid cascade hypothesis. Nat Neurosci 794-799.

[29] Kepp KP (2017) Ten Challenges of the Amyloid Hypothesis of Alzheimer's Disease. J. Alzheimer's Dis. 55, 447-457.

[30] Kepp KP (2016) Alzheimer's disease due to loss of function: A new synthesis of the available data. Prog. Neurobiol. 143, 36-60.

[31] Masters CL, Gajdusek DC, Gibbs CJJ (1981) The familial occurrence of CreutzfeldtJakob disease and Alzheimer's disease. Brain 104, 535-558. 
[32] Hardy J (2006) Alzheimer's disease: The amyloid cascade hypothesis - An update and reappraisal. J. Alzheimer's Dis. 9, 151-153.

[33] Chiti F, Dobson CM (2006) Protein misfolding, functional amyloid, and human disease. Annu. Rev. Biochem. 75, 333-366.

[34] Götz J, Eckert A, Matamales M, Ittner LM, Liu X (2011) Modes of A $\beta$ toxicity in Alzheimer's disease. Cell. Mol. Life Sci. 68, 3359-3375.

[35] Ono K, Condron MM, Teplow DB (2009) Structure-neurotoxicity relationships of amyloid beta-protein oligomers. Proc. Natl. Acad. Sci. U. S. A. 106, 14745-14750.

[36] Walsh DM, Klyubin I, Fadeeva J V, Cullen WK, Anwyl R, Wolfe MS, Rowan MJ, Selkoe DJ (2002) Naturally secreted oligomers of amyloid beta protein potently inhibit hippocampal long-term potentiation in vivo. Nature 416, 535-539.

[37] De Strooper B (2014) Lessons from a Failed $\gamma$-Secretase Alzheimer Trial. Cell 159, 721726.

[38] Morris GP, Clark IA, Vissel B (2014) Inconsistencies and controversies surrounding the amyloid hypothesis of Alzheimer's disease. Acta Neuropathol. Commun. 2, 135.

[39] Gidalevitz T, Ben-Zvi A, Ho KH, Brignull HR, Morimoto RI (2006) Progressive disruption of cellular protein folding in models of polyglutamine diseases. Science 311, $1471-1474$.

[40] Jarrett JT, Lansbury PT (1993) Seeding “one-dimensional crystallization” of amyloid: a pathogenic mechanism in Alzheimer's disease and scrapie? Cell 73, 1055-1058.

[41] Jaunmuktane Z, Mead S, Ellis M, Wadsworth JDF, Nicoll AJ, Kenny J, Launchbury F, Linehan J, Richard-Loendt A, Walker AS, Rudge P, Collinge J, Brandner S (2015) Evidence for human transmission of amyloid- $\beta$ pathology and cerebral amyloid angiopathy. Nature 525, 247-250.

[42] Sciacca MFM, Kotler SA, Brender JR, Chen J, Lee DK, Ramamoorthy A (2012) Two-step mechanism of membrane disruption by $\mathrm{A} \beta$ through membrane fragmentation and pore formation. Biophys. J. 103, 702-710.

[43] Kawahara M, Arispe N, Kuroda Y, Rojas E (1997) Alzheimer's disease amyloid beta- 
protein forms $\mathrm{Zn}(2+)$-sensitive, cation-selective channels across excised membrane patches from hypothalamic neurons. Biophys. J. 73, 67-75.

[44] Demuro A, Mina E, Kayed R, Milton SC, Parker I, Glabe CG (2005) Calcium dysregulation and membrane disruption as a ubiquitous neurotoxic mechanism of soluble amyloid oligomers. J. Biol. Chem. 280, 17294-17300.

[45] Wang Q, Johnson JL, Agar NYR, Agar JN (2008) Protein aggregation and protein instability govern familial amyotrophic lateral sclerosis patient survival. PLoS Biol. 6, e170.

[46] Stathopulos PB, Rumfeldt J a O, Scholz G a, Irani R a, Frey HE, Hallewell R a, Lepock JR, Meiering EM (2003) Cu/Zn superoxide dismutase mutants associated with amyotrophic lateral sclerosis show enhanced formation of aggregates in vitro. Proc. Natl. Acad. Sci. U. S. A. 100, 7021-6.

[47] De Strooper B, Saftig P, Craessaerts K, Vanderstichele H, Guhde G, Annaert W, Von Figura K, Van Leuven F (1998) Deficiency of presenilin-1 inhibits the normal cleavage of amyloid precursor protein. Nature 391, 387-390.

[48] Saura CA, Choi S-Y, Beglopoulos V, Malkani S, Zhang D, Shankaranarayana Rao BS, Chattarji S, Kelleher RJ 3rd, Kandel ER, Duff K, Kirkwood A, Shen J (2004) Loss of presenilin function causes impairments of memory and synaptic plasticity followed by age-dependent neurodegeneration. Neuron 42, 23-36.

[49] Saccon R a, Bunton-Stasyshyn RK a, Fisher EMC, Fratta P (2013) Is SOD1 loss of function involved in amyotrophic lateral sclerosis? Brain 136, 2342-2358.

[50] Shen J, Kelleher RJ (2007) The presenilin hypothesis of Alzheimer's disease: evidence for a loss-of-function pathogenic mechanism. Proc. Natl. Acad. Sci. U. S. A. 104, 403-409.

[51] Kepp KP, Dasmeh P (2014) A model of proteostatic energy cost and its use in analysis of proteome trends and sequence evolution. PLoS One 9, e90504.

[52] Drummond DA, Wilke CO (2008) Mistranslation-induced protein misfolding as a dominant constraint on coding-sequence evolution. Cell 134, 341-352.

[53] Drummond DA, Wilke CO (2009) The evolutionary consequences of erroneous protein 
synthesis. Nat. Rev. Genet. 10, 715-724.

[54] Reeds PJ, Fuller MF, Nicholson BA (1985) Metabolic basis of energy expenditure with particular reference to protein. Substrate energy Metab. man 46-57.

[55] Waterlow JC (1995) Whole-body protein turnover in humans - past, present, and future. Annu. Rev. Nutr. 15, 57-92.

[56] Harold FM (1987) The vital force: a study of bioenergetics, W.H. Freeman \& Company.

[57] Fraser KPP, Rogers AD (2007) Protein metabolism in marine animals: the underlying mechanism of growth. Adv. Mar. Biol. 52, 267-362.

[58] Attwell D, Laughlin SB (2001) An energy budget for signaling in the grey matter of the brain. J. Cereb. Blood Flow Metab. 21, 1133-1145.

[59] Raichle ME, Gusnard DA (2002) Appraising the brain's energy budget. Proc. Natl. Acad. Sci. 99, 10237-10239.

[60] Ames III A (2000) CNS energy metabolism as related to function. Brain Res. Rev. 34, 4268.

[61] Bélanger M, Allaman I, Magistretti PJ (2011) Brain energy metabolism: focus on astrocyte-neuron metabolic cooperation. Cell Metab. 14, 724-738.

[62] Engl E, Attwell D (2015) Non-signalling energy use in the brain. J. Physiol. 593, 34173429.

[63] Lu T, Pan Y, Kao S-Y, Li C, Kohane I, Chan J, Yankner BA (2004) Gene regulation and DNA damage in the ageing human brain. Nature 429, 883-891.

[64] Liang WS, Reiman EM, Valla J, Dunckley T, Beach TG, Grover A, Niedzielko TL, Schneider LE, Mastroeni D, Caselli R, Kukull W, Morris JC, Hulette CM, Schmechel D, Rogers J, Stephan DA (2008) Alzheimer's disease is associated with reduced expression of energy metabolism genes in posterior cingulate neurons. Proc. Natl. Acad. Sci. 105, $4441-4446$.

[65] Dunn L, Allen GF, Mamais A, Ling H, Li A, Duberley KE, Hargreaves IP, Pope S, Holton JL, Lees A, Heales SJ, Bandopadhyay R (2014) Dysregulation of glucose metabolism is an early event in sporadic Parkinson's disease. Neurobiol. Aging 35, 1111-1115. 
[66] Bateman RJ, Xiong C, Benzinger TLS, Fagan AM, Goate A, Fox NC, Marcus DS, Cairns NJ, Xie X, Blazey TM, Holtzman DM, Santacruz A, Buckles V, Oliver A, Moulder K, Aisen PS, Ghetti B, Klunk WE, McDade E, Martins RN, Masters CL, Mayeux R, Ringman JM, Rossor MN, Schofield PR, Sperling RA, Salloway S, Morris JC (2012) Clinical and biomarker changes in dominantly inherited Alzheimer's disease. N. Engl. J. Med. 367, 795-804.

[67] Lindberg MJ, Byström R, Boknäs N, Andersen PM, Oliveberg M (2005) Systematically perturbed folding patterns of amyotrophic lateral sclerosis (ALS)-associated SOD1 mutants. Proc. Natl. Acad. Sci. U. S. A. 102, 9754-9759.

[68] Zetterström P, Stewart HG, Bergemalm D, Jonsson PA, Graffmo KS, Andersen PM, Brännström T, Oliveberg M, Marklund SL (2007) Soluble misfolded subfractions of mutant superoxide dismutase-1s are enriched in spinal cords throughout life in murine ALS models. Proc. Natl. Acad. Sci. U. S. A. 104, 14157-14162.

[69] Furukawa Y, O’Halloran T V (2005) Amyotrophic lateral sclerosis mutations have the greatest destabilizing effect on the apo- and reduced form of SOD1, leading to unfolding and oxidative aggregation. J. Biol. Chem. 280, 17266-17274.

[70] Khare SD, Caplow M, Dokholyan N V (2006) FALS mutations in Cu, Zn superoxide dismutase destabilize the dimer and increase dimer dissociation propensity: a large-scale thermodynamic analysis. Amyloid 13, 226-235.

[71] Vassall KA, Stathopulos PB, Rumfeldt JAO, Lepock JR, Meiering EM (2006) Equilibrium thermodynamic analysis of amyotrophic lateral sclerosis-associated mutant apo $\mathrm{Cu}, \mathrm{Zn}$ superoxide dismutases. Biochemistry 45, 7366-7379.

[72] Jack CRJ, Knopman DS, Jagust WJ, Shaw LM, Aisen PS, Weiner MW, Petersen RC, Trojanowski JQ (2010) Hypothetical model of dynamic biomarkers of the Alzheimer's pathological cascade. Lancet. Neurol. 9, 119-128.

[73] Beal MF (1995) Aging, energy, and oxidative stress in neurodegenerative diseases. Ann. Neurol. 38, 357-366.

[74] Corona C, Pensalfini A, Frazzini V, Sensi SL (2011) New therapeutic targets in Alzheimer's disease: brain deregulation of calcium and zinc. Cell Death Dis. 2, e176. 
[75] Sensi SL, Ton-That D, Sullivan PG, Jonas EA, Gee KR, Kaczmarek LK, Weiss JH (2003) Modulation of mitochondrial function by endogenous Zn2+ pools. Proc. Natl. Acad. Sci. 100, 6157-6162.

[76] Pal A, Siotto M, Prasad R, Squitti R (2015) Towards a unified vision of copper involvement in Alzheimer's disease: a review connecting basic, experimental, and clinical research. J. Alzheimer's Dis. 44, 343-354.

[77] Zhang C, Rissman RA, Feng J (2015) Characterization of ATP alternations in an Alzheimer's disease transgenic mouse model. J. Alzheimers. Dis. 44, 375-378.

[78] Eckert A, Hauptmann S, Scherping I, Rhein V, Muller-Spahn F, Gotz J, Muller WE (2008) Soluble beta-amyloid leads to mitochondrial defects in amyloid precursor protein and tau transgenic mice. Neurodegener. Dis. 5, 157-159.

[79] Toda N, Ayajiki K, Okamura T (2014) Obesity-Induced Cerebral Hypoperfusion Derived from Endothelial Dysfunction: One of the Risk Factors for Alzheimer's Disease. Curr. Alzheimer Res. Curr. Alzheimer Res, Curr Alzh R, Curr Alzheimer Res 11, 733-744.

[80] McAuley MT, Kenny RA, Kirkwood TBL, Wilkinson DJ, Jones JJL, Miller VM (2009) A mathematical model of aging-related and cortisol induced hippocampal dysfunction. BMC Neurosci. 10, 26.

[81] Kety SS (1957) The general metabolism of the brain in vivo. In Metabolism of the nervous system Elsevier, pp. 221-237.

[82] Owen OE, Morgan AP, Kemp HG, Sullivan JM, Herrera MG, Cahill GFJ (1967) Brain metabolism during fasting. J. Clin. Invest. 46, 1589-1595.

[83] Magistretti PJ, Pellerin L (1999) Cellular mechanisms of brain energy metabolism and their relevance to functional brain imaging. Philos. Trans. R. Soc. London B Biol. Sci. 354, 1155-1163.

[84] Carvalho C, Correia SC, Santos RX, Cardoso S, Moreira PI, Clark TA, Zhu X, Smith MA, Perry G (2009) Role of mitochondrial-mediated signaling pathways in Alzheimer disease and hypoxia. J. Bioenerg. Biomembr. 41, 433-440.

[85] Zhang C, Lin M, Wu R, Wang X, Yang B, Levine AJ, Hu W, Feng Z (2011) Parkin, a p53 
target gene, mediates the role of p53 in glucose metabolism and the Warburg effect. Proc. Natl. Acad. Sci. U. S. A. 108, 16259-16264.

[86] Hoyer S (1996) Oxidative metabolism deficiencies in brains of patients with Alzheimer's disease. Acta Neurol. Scand. 94, 18-24.

[87] Ott A, Stolk RP, Hofman A, VanHarskamp F, Grobbee DE, Breteler MMB (1996) Association of diabetes mellitus and dementia: The Rotterdam study. Diabetologia 39, $1392-1397$.

[88] Willette AA, Bendlin BB, Starks EJ, Birdsill AC, Johnson SC, Christian BT, Okonkwo OC, La Rue A, Hermann BP, Koscik RL, Jonaitis EM, Sager MA, Asthana S (2015) Association of Insulin Resistance With Cerebral Glucose Uptake in Late Middle-Aged Adults at Risk for Alzheimer Disease. Jama Neurol. Jama Neurol, Jama Neurol 72, 10131020.

[89] Hipkiss AR (2017) On the Relationship between Energy Metabolism, Proteostasis, Aging and Parkinson's Disease: Possible Causative Role of Methylglyoxal and Alleviative Potential of Carnosine. Aging Dis. 8, 334-345.

[90] Kapogiannis D, Mattson MP (2011) Disrupted energy metabolism and neuronal circuit dysfunction in cognitive impairment and Alzheimer's disease. Lancet Neurol. 10, 187198.

[91] Genton L, Viatte V, Janssens J-P, Héritier A-C, Pichard C (2011) Nutritional state, energy intakes and energy expenditure of amyotrophic lateral sclerosis (ALS) patients. Clin. Nutr. 30, 553-559.

[92] Barnard ND, Bush AI, Ceccarelli A, Cooper J, de Jager CA, Erickson KI, Fraser G, Kesler S, Levin SM, Lucey B, Morris MC, Squitti R (2014) Dietary and lifestyle guidelines for the prevention of Alzheimer's disease. Neurobiol. Aging 35, S74-S78.

[93] Qiu C (2011) Epidemiological findings of vascular risk factors in Alzheimer's disease: implications for therapeutic and preventive intervention. Expert Rev. Neurother. Expert Rev. Neurother, Exp Rev Neu, Expert Rev Neurother 11, 1593-1607.

[94] Toledo JB, Toledo E, Weiner MW, Jack CR, Jagust W, Lee VM-Y, Shaw LM, Trojanowski JQ, Neuroimaging AD (2012) Cardiovascular risk factors, cortisol, and 
amyloid-beta deposition in Alzheimer's Disease Neuroimaging Initiative. Alzheimers Dementia, Alzheimer's Dementia, Alzheimers. Dement, Alzheimer D, Alzheimers Dement, Alzheimer's Dement. 8, 483-489.

[95] Mamelak M (2012) Sporadic Alzheimer's disease: the starving brain. J. Alzheimer's Dis. 31, 459-474.

[96] Mamelak M (2017) Energy and the Alzheimer brain. Neurosci. Biobehav. Rev. 75, 297313.

[97] Hoyer S (2000) Brain glucose and energy metabolism abnormalities in sporadic Alzheimer disease. Causes and consequences: an update. Exp. Gerontol. 35, 1363-1372.

[98] Dupuis L, Oudart H, René F, de Aguilar J-LG, Loeffler J-P (2004) Evidence for defective energy homeostasis in amyotrophic lateral sclerosis: benefit of a high-energy diet in a transgenic mouse model. Proc. Natl. Acad. Sci. 101, 11159-11164.

[99] Bowling AC, Schulz JB, Brown Jr RH, Beal MF (1993) Superoxide dismutase activity, oxidative damage, and mitochondrial energy metabolism in familial and sporadic amyotrophic lateral sclerosis. J. Neurochem. 61, 2322-2325.

[100] Rothstein JD (2009) Current hypotheses for the underlying biology of amyotrophic lateral sclerosis. Ann. Neurol. 65, S3-S9.

[101] Kepp KP (2015) Genotype-Property Patient-Phenotype Relations Suggest that Proteome Exhaustion Can Cause Amyotrophic Lateral Sclerosis. PLoS One 10, e0118649.

[102] Parker Jr WD, Boyson SJ, Parks JK (1989) Abnormalities of the electron transport chain in idiopathic Parkinson's disease. Ann. Neurol. 26, 719-723.

[103] Lin MT, Beal MF (2006) Mitochondrial dysfunction and oxidative stress in neurodegenerative diseases. Nature 443, 787-795.

[104] Beal MF, Hyman BT, Koroshetz W (1993) Do defecs in mitochondrial energy metabolism underlie the pathology of neurodegenerative diseases? Trends Neurosci. 16, 125-131.

[105] Cunnane S, Nugent S, Roy M, Courchesne-Loyer A, Croteau E, Tremblay S, Castellano A, Pifferi F, Bocti C, Paquet N (2011) Brain fuel metabolism, aging, and Alzheimer's disease. Nutrition 27, 3-20. 
[106] Caspersen C, Wang N, Yao J, Sosunov A, Chen X, Lustbader JW, Xu HW, Stern D, McKhann G, Yan S Du (2005) Mitochondrial A $\beta$ : a potential focal point for neuronal metabolic dysfunction in Alzheimer's disease. FASEB J. 19, 2040-2041.

[107] Lustbader JW, Cirilli M, Lin C, Xu HW, Takuma K, Wang N, Caspersen C, Chen X, Pollak S, Chaney M, Trinchese F, Liu S, Gunn-Moore F, Lue L-F, Walker DG, Kuppusamy P, Zewier ZL, Arancio O, Stern D, Yan SS, Wu H (2004) ABAD directly links Abeta to mitochondrial toxicity in Alzheimer's disease. Science 304, 448-452.

[108] Dragicevic N, Mamcarz M, Zhu Y, Buzzeo R, Tan J, Arendash GW, Bradshaw PC (2010) Mitochondrial amyloid-beta levels are associated with the extent of mitochondrial dysfunction in different brain regions and the degree of cognitive impairment in Alzheimer's transgenic mice. J. Alzheimers. Dis. 20 Suppl 2, S535-50.

[109] Manczak M, Anekonda TS, Henson E, Park BS, Quinn J, Reddy PH (2006) Mitochondria are a direct site of A beta accumulation in Alzheimer's disease neurons: implications for free radical generation and oxidative damage in disease progression. Hum. Mol. Genet. 15, 1437-1449.

[110] Chakroborty S, Stutzmann GE (2011) Early calcium dysregulation in Alzheimer's disease: Setting the stage for synaptic dysfunction. Sci. China Life Sci. 54, 752-762.

[111] Small DH (2009) Dysregulation of calcium homeostasis in Alzheimer's disease. Neurochem. Res. 34, 1824-1829.

[112] Demuro A, Parker I, Stutzmann GE (2010) Calcium signaling and amyloid toxicity in Alzheimer disease. J. Biol. Chem. 285, 12463-12468.

[113] Kawahara M, Negishi-Kato M, Sadakane Y (2009) Calcium dyshomeostasis and neurotoxicity of Alzheimer's beta-amyloid protein. Expert Rev. Neurother. 9, 681-693.

[114] Lal R, Lin H, Quist AP (2007) Amyloid beta ion channel: 3D structure and relevance to amyloid channel paradigm. Biochim. Biophys. Acta 1768, 1966-1975.

[115] DeToma AS, Salamekh S, Ramamoorthy A, Lim MH (2012) Misfolded proteins in Alzheimer's disease and type II diabetes. Chem. Soc. Rev. 41, 608-621.

[116] Ronnemaa E, Zethelius B, Sundelof J, Sundstrom J, Degerman-Gunnarsson M, Berne C, 
Lannfelt L, Kilander L (2008) Impaired insulin secretion increases the risk of Alzheimer disease. Neurol. Neurol. Neurol. 71, 1065-1071.

[117] De la Monte SM (2014) Type 3 diabetes is sporadic Alzheimer's disease: Mini-review. Eur. Neuropsychopharmacol. 24, 1-7.

[118] Kiddle SJ, Sattlecker M, Proitsi P, Simmons A, Westman E, Bazenet C, Nelson SK, Williams S, Hodges A, Johnston C, Soininen H, Kłoszewska I, Mecocci P, Tsolaki M, Vellas B, Newhouse S, Lovestone S, Dobson RJB (2014) Candidate blood proteome markers of Alzheimer's disease onset and progression: A systematic review and replication study. J. Alzheimer's Dis. 38, 515-531.

[119] Blass JP (2001) Brain metabolism and brain disease: Is metabolic deficiency the proximate cause of Alzheimer dementia? J. Neurosci. Res. 66, 851-856.

[120] Swerdlow RH (2011) Brain aging, Alzheimer's disease, and mitochondria. Biochim. Biophys. Acta - Mol. Basis Dis. 1812, 1630-1639.

[121] Morris JK, Honea RA, Vidoni ED, Swerdlow RH, Burns JM (2014) Is Alzheimer's disease a systemic disease? Biochim. Biophys. Acta - Mol. Basis Dis. 1842, 1340-1349.

[122] Burdo JR, Chen Q, Calcutt NA, Schubert D (2009) The pathological interaction between diabetes and presymptomatic Alzheimer's disease. Neurobiol. Aging 30, 1910-1917.

[123] Marchesini G, Bugianesi E, Ronchi M, Flamia R, Thomaseth K, Pacini G (1998) Zinc supplementation improves glucose disposal in patients with cirrhosis. Metab. - Clin. Exp. 47, 792-798.

[124] Cohen E, Bieschke J, Perciavalle RM, Kelly JW, Dillin A (2006) Opposing activities protect against age-onset proteotoxicity. Science 313, 1604-1610.

[125] Dasmeh P, Kepp KP (2017) Superoxide dismutase 1 is positively selected to minimize protein aggregation in great apes. Cell. Mol. Life Sci. 74, 3023-3037.

[126] Kepp KP (2014) Computing stability effects of mutations in human superoxide dismutase 1. J. Phys. Chem. B 118, 1799-1812.

[127] Bouteloup C, Desport J-C, Clavelou P, Guy N, Derumeaux-Burel H, Ferrier A, Couratier P (2009) Hypermetabolism in ALS patients: an early and persistent phenomenon. $J$. 
Neurol. 256, 1236-1242.

[128] Richardson K, Allen SP, Mortiboys H, Grierson AJ, Wharton SB, Ince PG, Shaw PJ, Heath PR (2013) The effect of SOD1 mutation on cellular bioenergetic profile and viability in response to oxidative stress and influence of mutation-type. PLoS One $\mathbf{8}$, e68256.

[129] Mattiazzi M, D’Aurelio M, Gajewski CD, Martushova K, Kiaei M, Beal MF, Manfredi G (2002) Mutated human SOD1 causes dysfunction of oxidative phosphorylation in mitochondria of transgenic mice. J. Biol. Chem. 277, 29626-29633.

[130] Browne SE, Yang L, DiMauro J-P, Fuller SW, Licata SC, Beal MF (2006) Bioenergetic abnormalities in discrete cerebral motor pathways presage spinal cord pathology in the G93A SOD1 mouse model of ALS. Neurobiol. Dis. 22, 599-610.

[131] Dupuis L, Gonzalez de Aguilar J-L, Echaniz-Laguna A, Eschbach J, Rene F, Oudart H, Halter B, Huze C, Schaeffer L, Bouillaud F, Loeffler J-P (2009) Muscle mitochondrial uncoupling dismantles neuromuscular junction and triggers distal degeneration of motor neurons. PLoS One 4, e5390.

[132] Bastow EL, Peswani AR, Tarrant DSJ, Pentland DR, Chen X, Morgan A, Staniforth GL, Tullet JM, Rowe ML, Howard MJ (2016) New links between SOD1 and metabolic dysfunction from a yeast model of amyotrophic lateral sclerosis. J Cell Sci 129, 41184129.

[133] Kitamura A, Inada N, Kubota H, Matsumoto G, Kinjo M, Morimoto RI, Nagata K (2014) Dysregulation of the proteasome increases the toxicity of ALS-linked mutant SOD1. Genes Cells 19, 209-224.

[134] Perera ND, Turner BJ (2016) AMPK signalling and defective energy metabolism in amyotrophic lateral sclerosis. Neurochem. Res. 41, 544-553.

[135] Deng H-X, Chen W, Hong S-T, Boycott KM, Gorrie GH, Siddique N, Yang Y, Fecto F, Shi Y, Zhai H, Jiang H, Hirano M, Rampersaud E, Jansen GH, Donkervoort S, Bigio EH, Brooks BR, Ajroud K, Sufit RL, Haines JL, Mugnaini E, Pericak-Vance MA, Siddique T (2011) Mutations in UBQLN2 cause dominant X-linked juvenile and adult-onset ALS and ALS/dementia. Nature 477, 211-215. 
[136] Renton AE, Majounie E, Waite A, Simón-Sánchez J, Rollinson S, Gibbs JR, Schymick JC, Laaksovirta H, van Swieten JC, Myllykangas L, Kalimo H, Paetau A, Abramzon Y, Remes AM, Kaganovich A, Scholz SW, Duckworth J, Ding J, Harmer DW, Hernandez DG, Johnson JO, Mok K, Ryten M, Trabzuni D, Guerreiro RJ, Orrell RW, Neal J, Murray A, Pearson J, Jansen IE, Sondervan D, Seelaar H, Blake D, Young K, Halliwell N, Callister JB, Toulson G, Richardson A, Gerhard A, Snowden J, Mann D, Neary D, Nalls M a, Peuralinna T, Jansson L, Isoviita V-M, Kaivorinne A-L, Hölttä-Vuori M, Ikonen E, Sulkava R, Benatar M, Wuu J, Chiò A, Restagno G, Borghero G, Sabatelli M, Heckerman D, Rogaeva E, Zinman L, Rothstein JD, Sendtner M, Drepper C, Eichler EE, Alkan C, Abdullaev Z, Pack SD, Dutra A, Pak E, Hardy J, Singleton A, Williams NM, Heutink P, Pickering-Brown S, Morris HR, Tienari PJ, Traynor BJ (2011) A hexanucleotide repeat expansion in C9ORF72 is the cause of chromosome 9p21-linked ALS-FTD. Neuron 72, $257-268$.

[137] Sreedharan J, Blair IP, Tripathi VB, Hu X, Vance C, Rogelj B, Ackerley S, Durnall JC, Williams KL, Buratti E, Baralle F, de Belleroche J, Mitchell JD, Leigh PN, Al-Chalabi A, Miller CC, Nicholson G, Shaw CE (2008) TDP-43 mutations in familial and sporadic amyotrophic lateral sclerosis. Science 319, 1668-1672.

[138] Strong MJ (2010) The evidence for altered RNA metabolism in amyotrophic lateral sclerosis (ALS). J. Neurol. Sci. 288, 1-12.

[139] Kwiatkowski TJ, Bosco DA, Leclerc AL, Tamrazian E, Vanderburg CR, Russ C, Davis A, Gilchrist J, Kasarskis EJ, Munsat T, Valdmanis P, Rouleau GA, Hosler BA, Cortelli P, de Jong PJ, Yoshinaga Y, Haines JL, Pericak-Vance MA, Yan J, Ticozzi N, Siddique T, McKenna-Yasek D, Sapp PC, Horvitz HR, Landers JE, Brown RH (2009) Mutations in the FUS/TLS gene on chromosome 16 cause familial amyotrophic lateral sclerosis. Science 323, 1205-1208.

[140] Vance C, Rogelj B, Hortobágyi T, De Vos KJ, Nishimura AL, Sreedharan J, Hu X, Smith B, Ruddy D, Wright P, Ganesalingam J, Williams KL, Tripathi V, Al-Saraj S, Al-Chalabi A, Leigh PN, Blair IP, Nicholson G, de Belleroche J, Gallo J-M, Miller CC, Shaw CE (2009) Mutations in FUS, an RNA processing protein, cause familial amyotrophic lateral sclerosis type 6. Science 323, 1208-1211. 
[141] Fecto F, Yan J, Vemula SP, Liu E, Yang Y, Chen W, Zheng JG, Shi Y, Siddique N, Arrat H, Donkervoort S, Ajroud-Driss S, Sufit RL, Heller SL, Deng H-X, Siddique T (2011) SQSTM1 mutations in familial and sporadic amyotrophic lateral sclerosis. Arch. Neurol. 68, 1440-1446.

[142] Johnson JO, Mandrioli J, Benatar M, Abramzon Y, Van Deerlin VM, Trojanowski JQ, Gibbs JR, Brunetti M, Gronka S, Wuu J, Ding J, McCluskey L, Martinez-Lage M, Falcone D, Hernandez DG, Arepalli S, Chong S, Schymick JC, Rothstein J, Landi F, Wang Y-D, Calvo A, Mora G, Sabatelli M, Monsurrò MR, Battistini S, Salvi F, Spataro R, Sola P, Borghero G, Galassi G, Scholz SW, Taylor JP, Restagno G, Chiò A, Traynor BJ (2010) Exome sequencing reveals VCP mutations as a cause of familial ALS. Neuron 68, 857-864.

[143] Somalinga BR, Day CE, Wei S, Roth MG, Thomas PJ (2012) TDP-43 identified from a genome wide RNAi screen for SOD1 regulators. PLoS One 7, e35818.

[144] Jaarsma D, Haasdijk ED, Grashorn JA, Hawkins R, van Duijn W, Verspaget HW, London J, Holstege JC (2000) Human Cu/Zn superoxide dismutase (SOD1) overexpression in mice causes mitochondrial vacuolization, axonal degeneration, and premature motoneuron death and accelerates motoneuron disease in mice expressing a familial amyotrophic lateral sclerosis mutant SO. Neurobiol. Dis. 7, 623-643.

[145] Somalinga BR, Miller GA, Malik HT, Wigley WC, Thomas PJ (2011) A screen to identify cellular modulators of soluble levels of an amyotrophic lateral sclerosis (ALS)-causing mutant SOD1. J. Biomol. Screen. 16, 974-985.

[146] Gej1 M, Gjedde A, Egefjord L, Møller A, Hansen SB, Vang K, Rodell A, Brændgaard H, Gottrup H, Schacht A (2016) In Alzheimer's disease, 6-month treatment with GLP-1 analog prevents decline of brain glucose metabolism: randomized, placebo-controlled, double-blind clinical trial. Front. Aging Neurosci. 8, 108. 
Neurovascular

genetic risk factors

Impaired glucose metabolism

(e.g. diabetes)

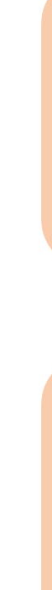

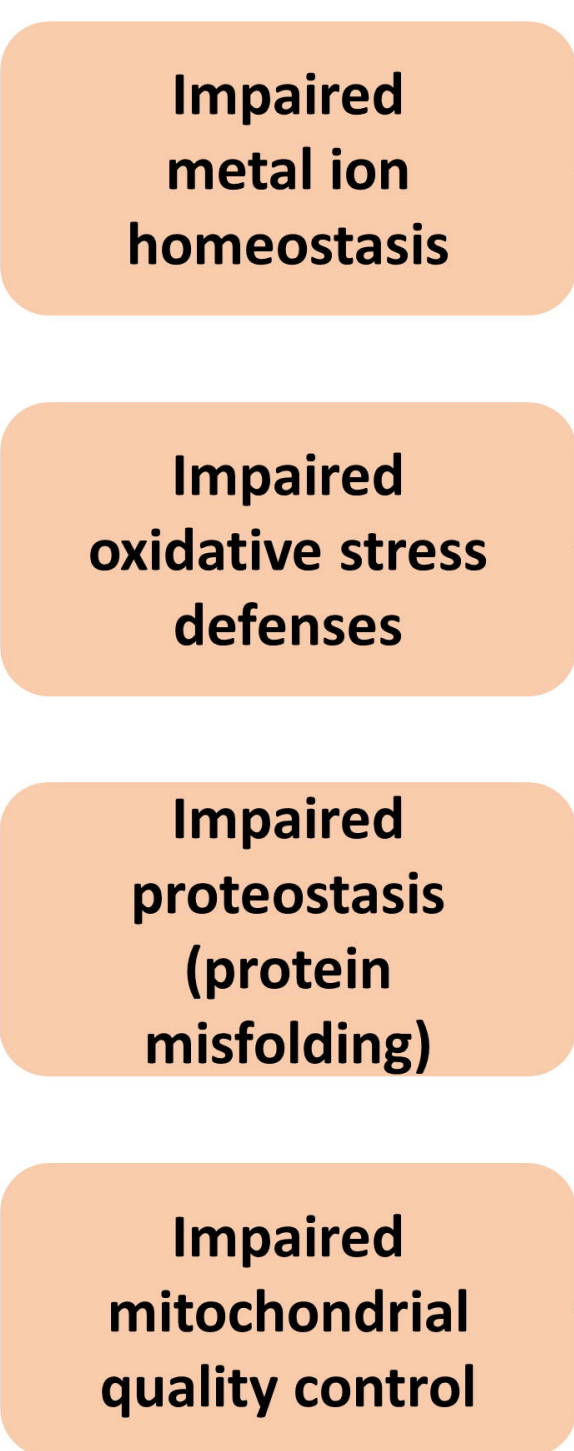

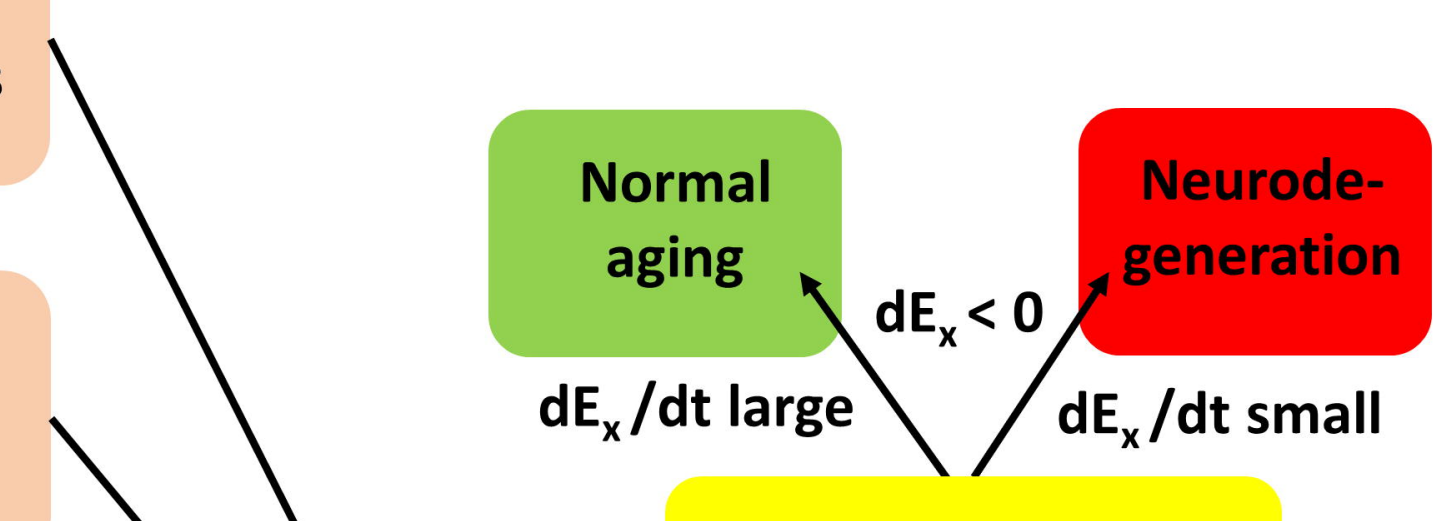

Neurovascular compromised

life style

Imbalanced

metabolic lifestyle

\section{Energy status} $d E_{x}=d E_{t}-d E_{m}$

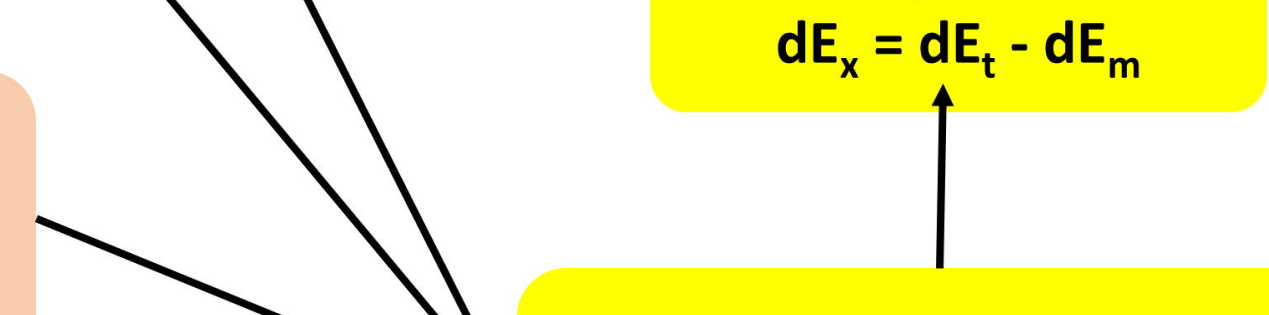

\section{Mitochondrial integrity}

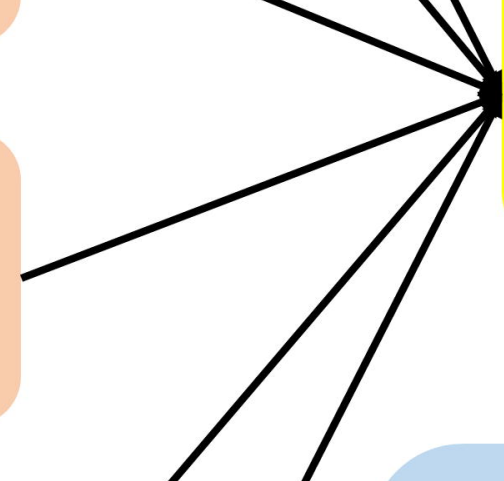

$d E_{m}$ increases

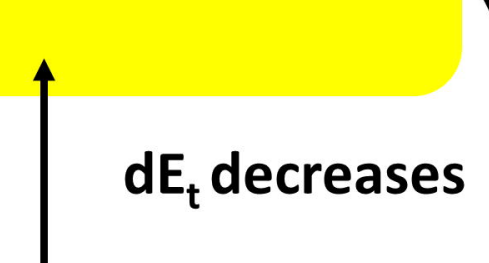

Chemical aging mitochondrial mutations oxidative stress accumulation metal ion dyshomeostasis accumulated neuronal injuries

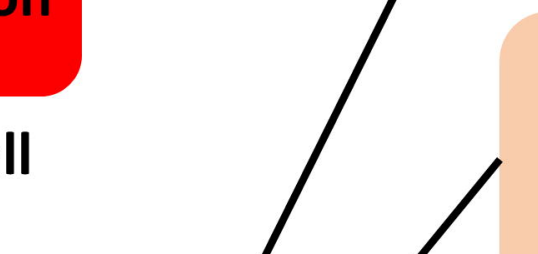

Specific oxidative stress from life style or exposure

Metal ion homeostasis disruption

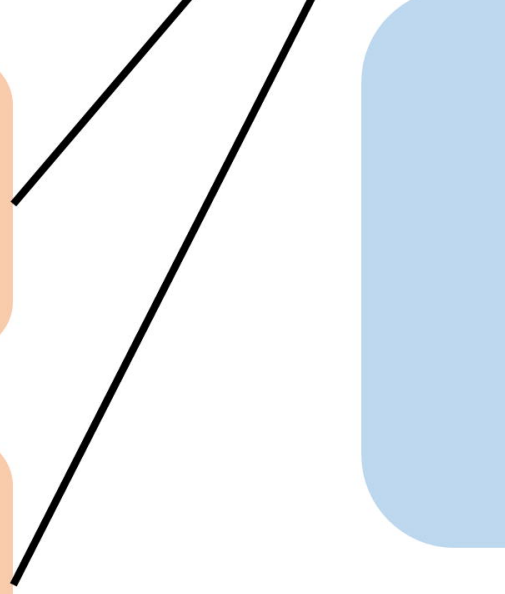

Neuronal insults from life time events life style 
